
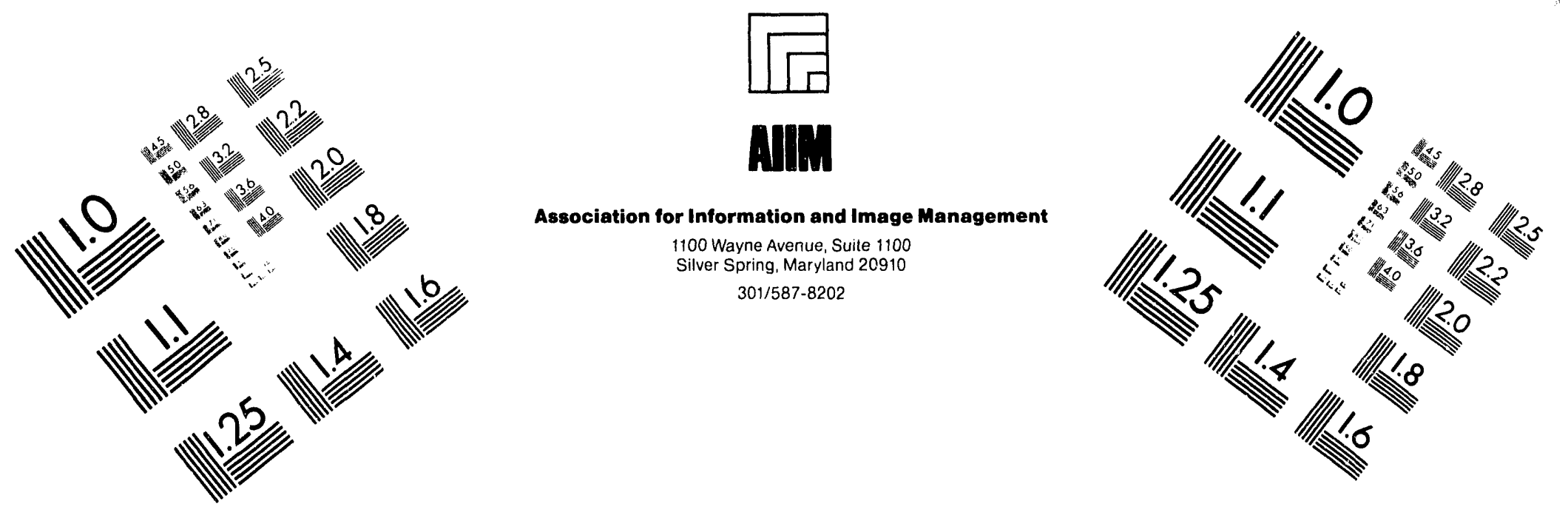

\title{
Centimeter
}

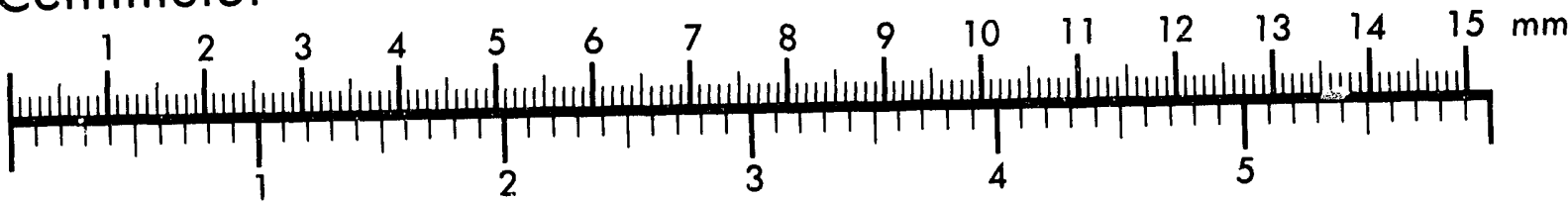

Inches
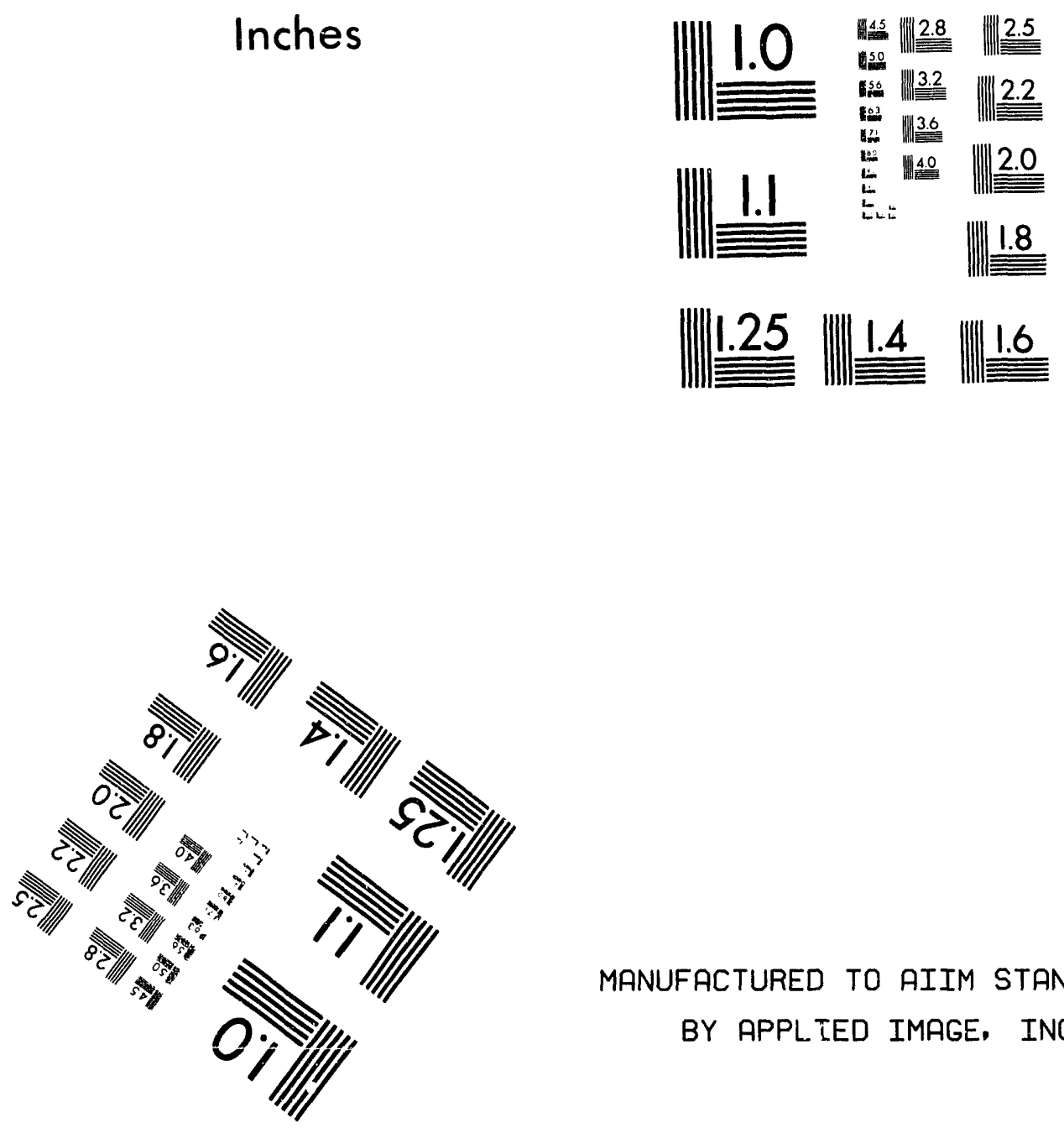

MANUFACTURED TO AIIM STANDARDS

BY APPLIED IMAGE, INC.

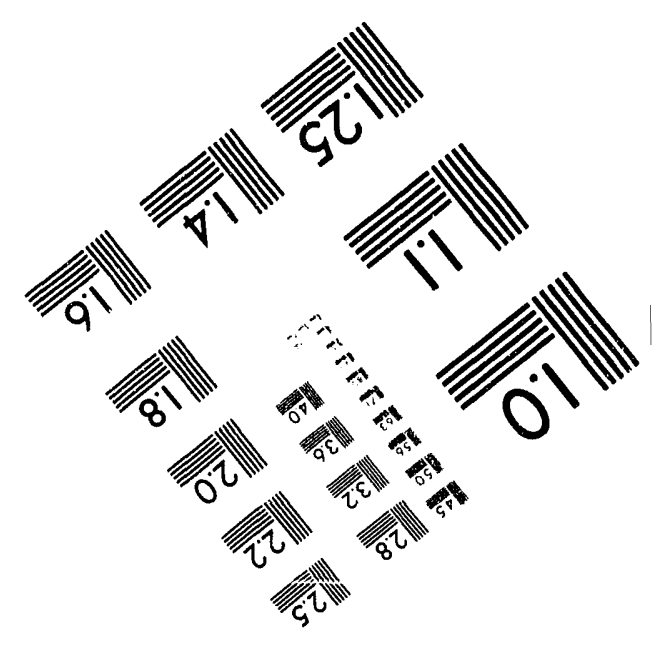



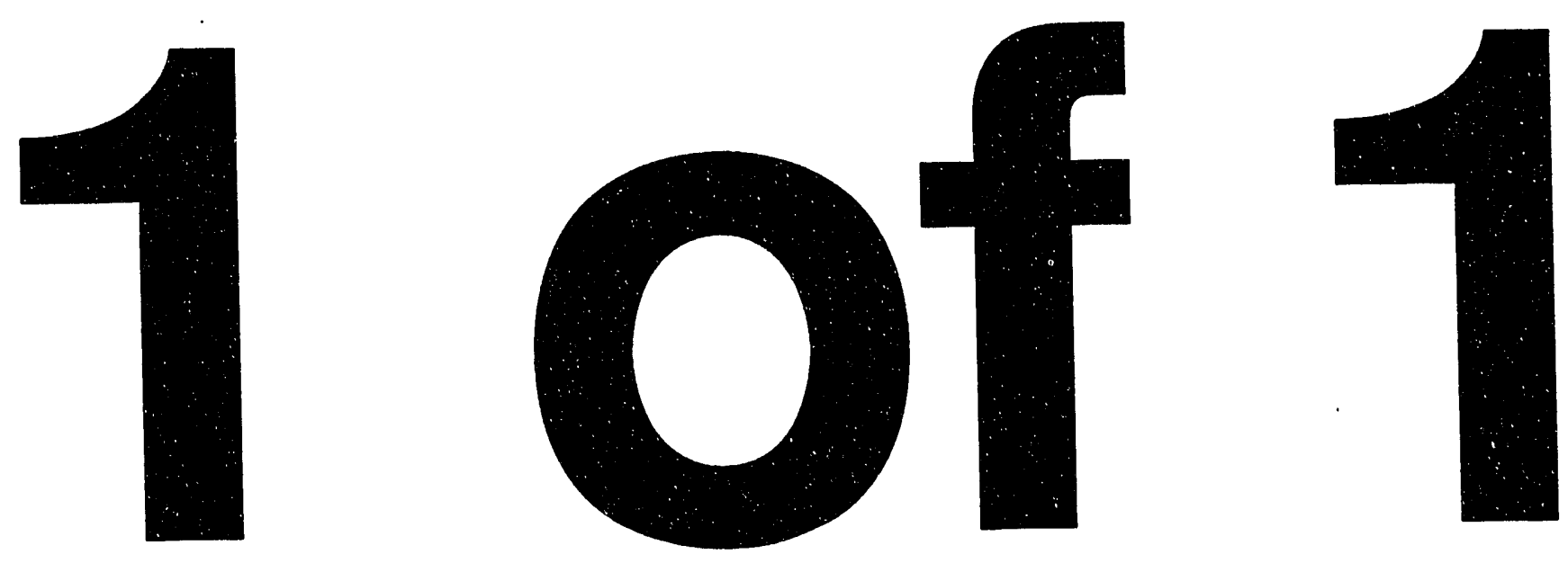
WSRC-TR-93-10:

$\operatorname{Rev} 0$

\section{Savannah River Site Disaggregated Seismic Spectra}

Westinghouse Savannah River Company

Savannah River Site

Aiken, SC 19808

Prepared for the U.S. Department of Energy under contract no. DE-AC09-89SR18035 


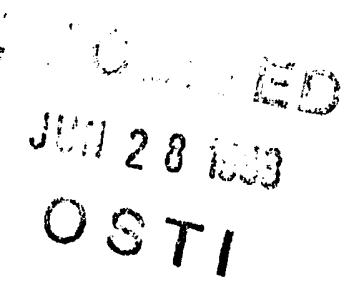

\section{DISCLAIMER}

This report was prepared as an account of work sponsored by an agency of the United States Government. Neither the United States Government nor any agency thereof, nor any of their employees, makes any warranty, express or implied, or assumes any legal liability or responsibility for the accuracy, completeness, or usefulness of any information, apparatus, product, or process disclosed, or represents that its use would not infringe privately owned rights. Reference herein to any specific commercial product, process, or service by trade name, trademark, manufacturer, or otherwise does not necessarily constitute or imply its endorsement, recommendation, or favoring by the United States Government or any agency thereof. The views and opinions of authors expressed herein do not necessarily state or reflect those of the United States Government or any agency thereof.

This report has been reproduced directly from the best available copy.

Available to DOE and DOE contractors from the Office of Scientific and Technical Information, P. O. Box 62, Oak Ridge, TN 37831; prices available from (615) $576-8401$.

Available to the public from the National Technical Information Service, U. S. Department of Commerce, 5285 Port Royal Rd., Springfield, VA 22161. 


\title{
Savannah River Site Disaggregated Seismic Spectra
}

\author{
Prepared by the Savannah River Technology Center-Environmental Sciences Section \\ D. E. Stephenson
}

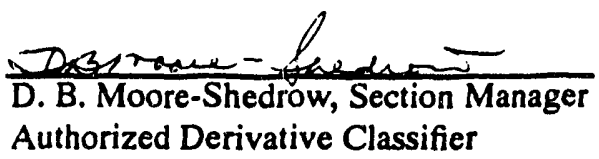

Prepared for the U.S. Department of Energy under contract no. DE-AC09-89SR18035 


\title{
Savannah River Site Disaggregated Seismic Spectra
}

\author{
D. E. Stephenson
}

\section{Objective}

The objective of this technical note is to characterize seismic ground motion at the Savannah River Site (SRS) by postulated earthquakes that may impact facilities at the site. This task is accomplished by reviewing the deterministic and probabilistic assessments of the seismic hazard to establish the earthquakes that control the hazard at the site and then evaluate the associated seismic grounu motions in terms of response spectra.

\section{Introduction}

For engineering design criteria of earthquake-resistant structures, response spectra serve the function of characterizing ground motions as a function of period or frequency. These motions then provide the input parameters that are used in the analysis of structural response. Because they use the maximum response, the response spectra are an inherently conservative design tool. Response spectra are described in terms of amplitude, duration, and frequency content, and these are related to source parameters, travel path, and site conditions. Studies by a number of investigators have shown by statistical analysis that for different magnitudes the response spectrum values are different for differing periods. These facts support Jennings' (1983) position that using different shapes of design spectra for earthquakes of different magnitudes and travel paths is a better practice than employing a single, general-purpose shape. In the Standard Review Plan (1981), the U. S. Nuclear Regulatory Commission (USNRC) states that several different earthquakes produce large ground motions in different frequency bands at a site; therefore, it is acceptable to use an ensemble of ground motion time histories from earthquakes with similar size, site-source characteristics, and spectral characteristics.

\section{Background}

During the present and past decade, deterministic seismic hazard analyses of SRS were performed and response spectra for ground motion calculated. In the 1982 Blume study, a spectrum was developed from two events, one local and one near Charleston, SC. In the 1991 Geomatrix study, the following three possible sources were identified: Charleston at $120 \mathrm{~km}$; Bowman, SC, at $60 \mathrm{~km}$; and a local source at less than $30 \mathrm{~km}$ (with the Bowman source motions being enveloped by the local and Charleston sources). Also during the 1980 s, two probabilistic seismic hazard analyses (PSHAs) were performed for SRS. Lawrence Livermore National Laboratory (LLNL) performed a study using the input and methods developed through support of the USNRC. The other analysis was performed by Jack Benjamin and Associates using the input and methods developed by the Electric Power Research Institute (EPRI) for the electric utilitie;

\section{Methods and Results}

As pointed out by the National Research Council's 1988 report by a panel on seismic hazard analysis for the eastern U. S., the results of PSHAs and deterninistic methods may be different because of low recurrence rates. For this reason, the panel recommended that the results of a PSHA be disaggregated to determine which seismic sources dominate the hazard at a site. This was done for SRS by the two organizations that performed the original PSHAs to identify the sources controlling the hazard at the site. Figures 1 and 2 show the results of disaggregating the PSHA for SRS. The LLNL results in Figure 1 show the percent hazard contribution as a funcrion of magnitude and distance. Figure 2 shows the EPR 1 results with a peak ground acceleration (PGA) of $0.20 \mathrm{~g}$ (the site's design basis) as a function of magnitude and distance. These results are summarized in Table 1. As can be seen from these studics, two seismic sources-a local event with $R<30 \mathrm{~km}$ and a larger source in the vicinity of Charleston-control the seismic hazard at SRS. These results compare favorably with the deterministic analyses performet for the site.

Recommendations of spectral shapes are considered f: $:$ m those presented in the deterministic analysis made by URS/Blume (1982) and more recently by the Geomatrix (1991) evaluation for the K Reactor. In the Blume analysis, the recommended site acceleration and spectra were recommended based on earthquakes, anticipated ground 
motions and synthetic scismograms for those events, and a PSHA. Two hypothetical earthquakes consistent with the size of carthquakes that have historically occurred in sinilar geologic environments were found to be controlling both SRS spectra and ground motions: (1) a hypothetical site intensity VII (MMI) local earthquake of epicentral intensity VII, causing an estimated site acceleration of 0.1 g; and (2) a hypothetical intensity X (like 1886 Charleston) carthquake, occurring at a closer distance of $95 \mathrm{~km}$ and causing an estimated site acceleration of about $0.1 \mathrm{~g}$. As a conservative approach, a site PGA of $0.2 \mathrm{~g}$ was selected that corresponded to a site intensity of VIII. Synthetic seismograms were also incorporated into the analysis and suggested a PGA of $0.08 \mathrm{~g}$ fior the Charleston carthquake $\left(\mathrm{M}_{\mathrm{b}}=6.6\right)$ and approximately $0.1-0.26 \mathrm{~g}$ for the local event $\left(M_{b}=5.2\right)$, depending on source distance. The spectra developed by this study is very similar to that provided in LLNL report UCRL 53582 (1984).

Gcomatrix (1991) performed a deterministic analysis as required by Appendix A to $10 \mathrm{CFR}$, Part 100 . The report for $\mathrm{K}$ Reactor recommended spectra for a Charleston source $\left(M_{w}=7.5\right.$, at $\left.120 \mathrm{~km}\right)$ and a local source $\left(M_{w}=5\right)$. The spectra were developed using Random Vibration Theory for the Charleston source and site-specific soils data. Western U. S. strong-motion data (from deep soil sites) were corrected for eastern U. S. soil conditions for the local event.

Based on the two deterministic studies, an interim position was established for the Replacement Tritium Facility recommending the use of the spectra developed for the Charleston event and a local event (Stephenson and Lee 1992).

For liquefaction studies, the use of spectra for a specific earthquake and site-specific soil properties is recommended for design rather than envelope spectra such as that recommended in the Blume report. The Blume report contains separate local and Charleston-type spectra that can be compared to the median $5 \%$ critically damped spectra contained in the Geomatrix report (Tables 2 and 3 ). Figures 3 and 4 are comparisons of the local and Charleston spectra for the two reports. The $\mathbf{M}_{w} 5$ "Corrected median scaled to eastern U.S." of the Geomatrix report is plotted with the Blume local spectra scaled to $0.1 \mathrm{~g}$. Figure 4 illustrates the Blume Charleston-type spectra and the smoothed Gcomatrix $M_{w} 7.5$ spectra ( $S D=150$ bars). We recommend the Geomatrix local/Charleston spectra (scaled to $0.2 \mathrm{~g}$ for the local event and $0.11 \mathrm{~g}$ for the Charleston event) be used because the site-specific soils data incorporated into that study was not available for the Blume analysis.

\section{Conclusions}

All seismic ground motion characterization results indicate that the PGA is controlled by a local event with $M_{w}<6$ and $\mathrm{R}<30 \mathrm{~km}$. The results also show that lower frequencies are controlled by a larger, more distant event, typically the Charleston source. The PGA of $0.2 \mathrm{~g}$, based originally on the Blume study, is consistent with LLNL report UCRL-15910 (1990) and with the DOE position on LLNL/EPRI. UCRL-19510 specifies that a median spectral shape can be used, and the Blume spectra shape is also generally consistent with that recommended by UCRL15910. The recommended Geomatrix spectral shape is consistent with that developed by LLNL for the NPR and with available data.

\section{References}

Coats, D. W. and R. C. Murray, 1984, Natural Phenomena Hazards Modeling Project: Seismic Hazard Models for Department of Energy Sites, Lawrence Livermore National Laboratory, UCRL-53582, Rev 1, Livermore, CA.

Geomatrix Consultants, 1991, Ground Motion Following Selection of SRS Design Basis Earthquake and Associated Deterministic Approach, prepared for Westınghouse Savannah River Company, WSRC-TR-91-124, San Francisco, CA.

Jennings, P. C., 1983, "Earthquake Observation, Theory, and Interpretation", H. Kanamori and E. Boschi (Eds.), Proceedings of the International School of Physics, 1982, Enrico Fermi, Course LXXXV, North Holland Publishing Co., Amsterdam, pp 138-171.

Kennedy, R. P., S. A. Short, J. R. McDonald, M. W. McCann, Jr., R. C. Murray, Jr., and J. R. Hill, 1990, Design and Evaluation Guidelines for Department of Energy Facilities Subjected to Natural Phenomena Hazards, prepared for the U. S. Department of Energy, UCRL-15910, Livermore, CA.

Stephenson, D. E. and R. C. Lee, 1992, Interim Position on Seismic Spectra for the Replacement Tritium Facility, SRT-ESS-92-0540, Westinghouse Savannah River Company, Aiken, SC.

URS/John A. Blume \& Assoc., Enginecring, 1982, Update of Seismic Criteria for the Savannah River Plant, prepared for E. I. du Pont de Nemours and Company, DPE 3699, San Francisco, CA. 
Table 1. LLNL and EPRI Seismic Hazard Results

LLNL Seismic Hazard Results (Vogtle), Prob $=1 \times 10 E^{-4}$

\begin{tabular}{ccc}
$\begin{array}{c}\text { Ground Motion } \\
\text { Parameter }\end{array}$ & Magnitude & Distance \\
\hline PGA & 5.60 & $26 \mathrm{~km}$ \\
Avg 5/10 HZ & 5.75 & $29 \mathrm{~km}$ \\
Avg $1 / 2.5 \mathrm{HZ}$ & 6.25 & $63 \mathrm{~km}$
\end{tabular}

EPRI Seismic Hazard Results (SRS) at PGA $=0.20 \mathrm{~g}$

Mean Magnitude

Mean Distance

5.9

$31 \mathrm{~km}$ 

Table 2. Acceleration recommended for SR.S from Table 3, $\begin{aligned} & \text { Acceleration for Char!eston-type carth- } \\ & \text { local carthquake. }\end{aligned}$

\begin{tabular}{|c|c|c|c|c|c|}
\hline Period & Blume (g) & $\begin{array}{l}\text { Geomatrix } \\
\text { (Eastern U. S.) }\end{array}$ & Period & Blume (g) & $\begin{array}{l}\text { Geomatrix } \\
\text { (Eastern U.S.) }\end{array}$ \\
\hline 0.02 & 0.1 & 0.2 & 0.01 & & 0.11 \\
\hline 0.04 & 0.1 & 0.27 & 0.02 & & 0.115 \\
\hline 0.05 & 0.111 & 0.28 & 0.03 & & 0.122 \\
\hline 0.06 & 0.121 & 0.31 & 0.04 & 0.01 & 0.14 \\
\hline 0.07 & 0.131 & 0.31 & 0.05 & 0.11 & 0.158 \\
\hline 0.08 & 0.14 & 0.32 & 0.06 & 0.12 & 0.176 \\
\hline 0.09 & 0.153 & 0.33 & 0.07 & 0.133 & 0.187 \\
\hline 0.1 & 0.165 & 0.33 & 0.08 & 0.145 & 0.196 \\
\hline 0.15 & 0.2 & 0.29 & 0.09 & 0.153 & 0.2 \\
\hline 0.2 & 0.255 & 0.25 & 0.1 & 0.16 & 0.212 \\
\hline 0.25 & 0.265 & 0.22 & 0.15 & 0.195 & 0.23 \\
\hline 0.3 & 0.255 & 0.2 & 0.2 & 0.23 & 0.225 \\
\hline 0.4 & 0.2 & 0.18 & 0.3 & 0.27 & 0.212 \\
\hline 0.5 & 0.15 & 0.17 & 0.4 & 0.26 & 0.21 \\
\hline 0.6 & 0.13 & 0.13 & 0.5 & 0.24 & 0.212 \\
\hline 0.7 & 0.11 & 0.11 & 0.6 & 0.21 & 0.215 \\
\hline 0.8 & 0.105 & 0.09 & 0.7 & 0.185 & 0.212 \\
\hline 0.9 & 0.088 & 0.07 & 0.8 & 0.175 & 0.204 \\
\hline 1.0 & 0.07 & 0.05 & 0.9 & 0.17 & 0.193 \\
\hline 1.5 & 0.047 & 0.02 & 1.0 & 0.165 & C. 181 \\
\hline 2.0 & 0.032 & 0.02 & 1.5 & 0.123 & 0.141 \\
\hline 3.0 & 0.021 & 0.005 & 2.0 & 0.08 & 0.105 \\
\hline 4.0 & 0.01 & & 3.0 & 0.058 & 0.058 \\
\hline 5.0 & 0.006 & & 4.0 & 0.036 & 0.033 \\
\hline 6.0 & 0.006 & & 5.0 & 0.028 & 0.02 \\
\hline 7.0 & 0.0045 & & 6.0 & 0.019 & 0.018 \\
\hline 8.0 & 0.003 & & 7.0 & 0.014 & 0.013 \\
\hline 9.0 & 0.0025 & & 8.0 & 0.009 & 0.009 \\
\hline \multirow[t]{2}{*}{10} & 0.002 & & 9.0 & 0.007 & 0.005 \\
\hline & & & 10 & 0.006 & 0.002 \\
\hline
\end{tabular}




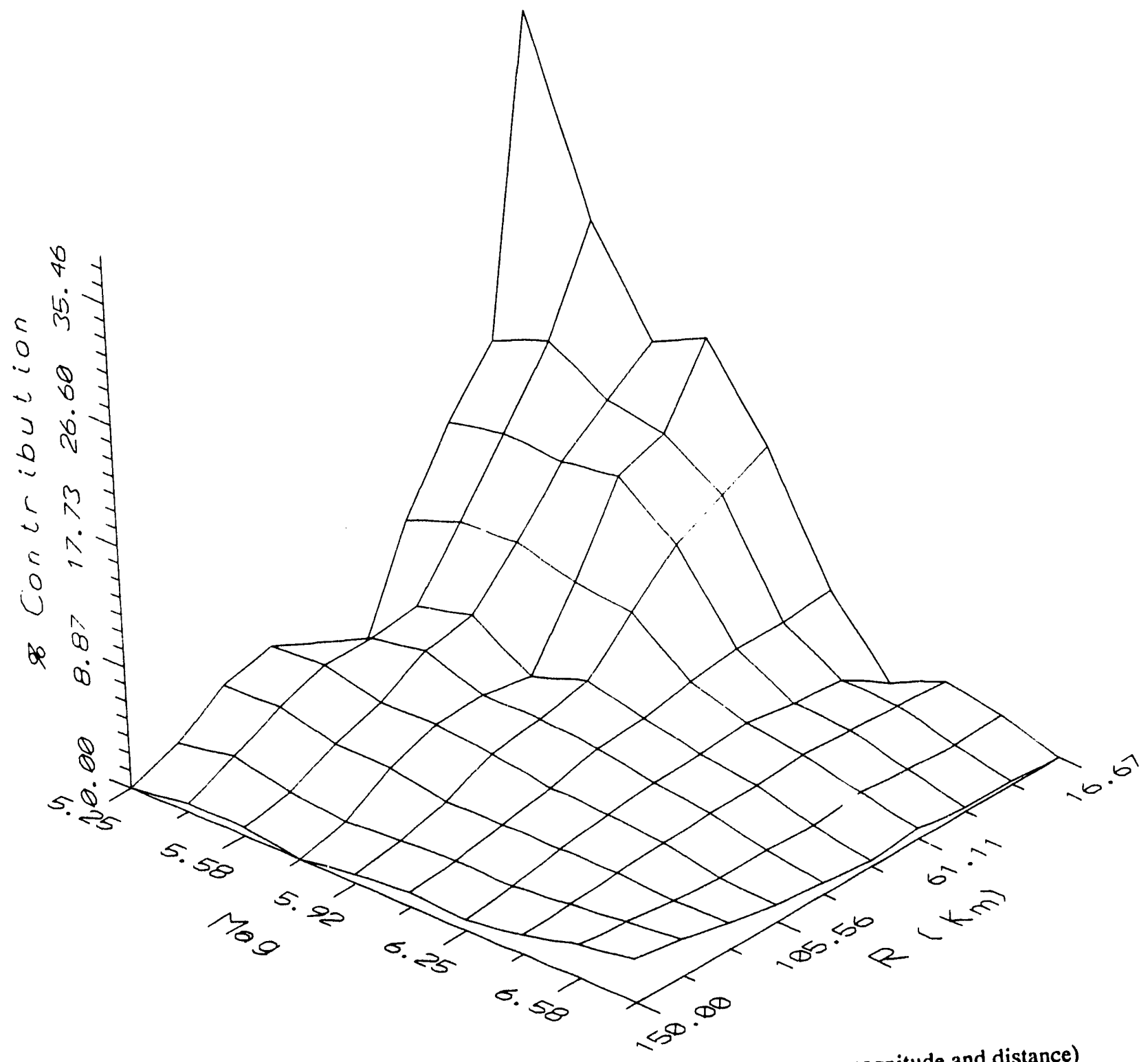

Figure 1. LLNL mean hazard model for SK $\mathrm{S}$ (\% contribution by source magnitude and distance) 
WSRC-TR-93-102

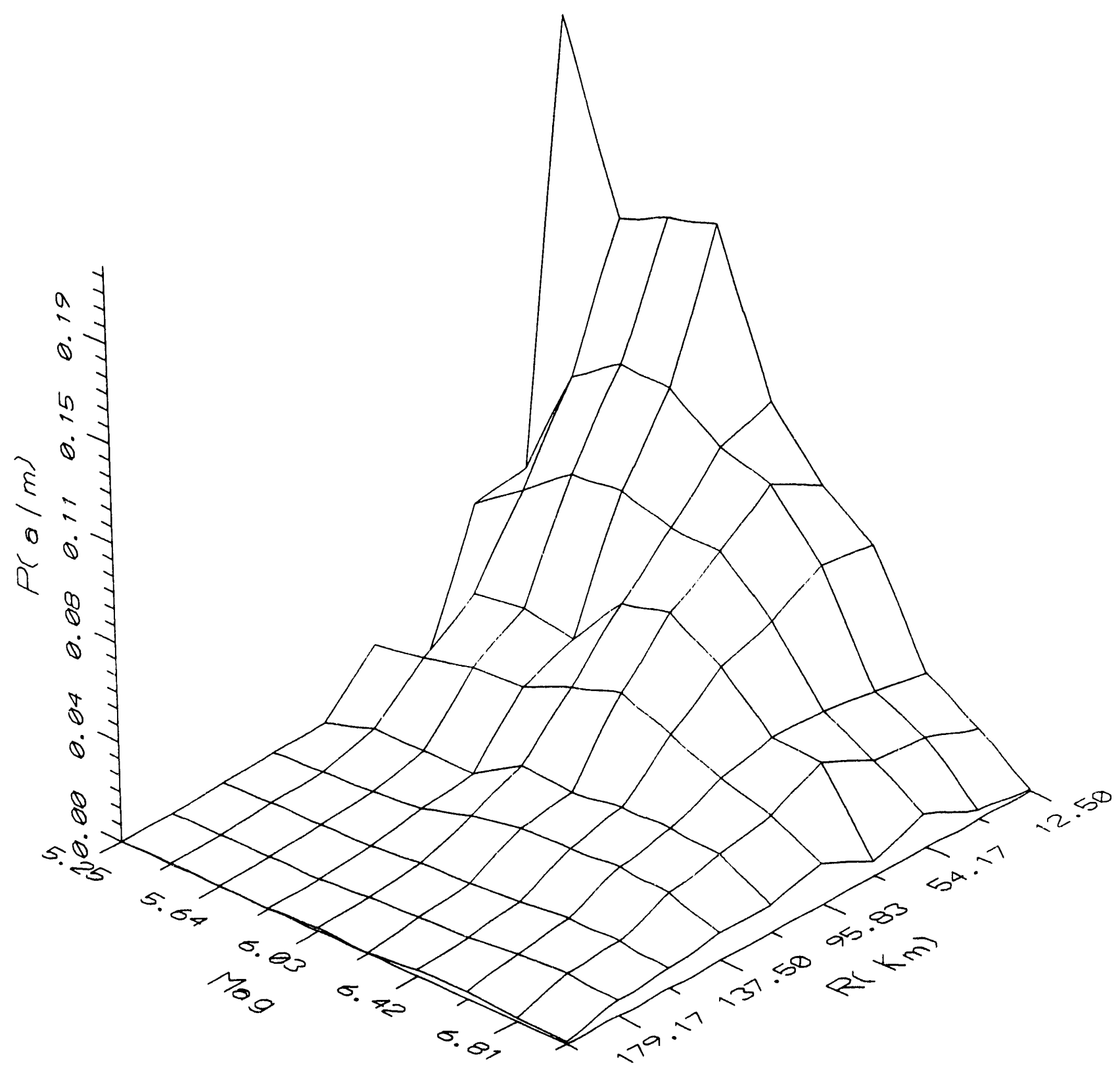

Figure 2. EPRI hazard for SRS (probability of exceeding $0.2 \mathrm{~g}$ given source magnitude and distance)

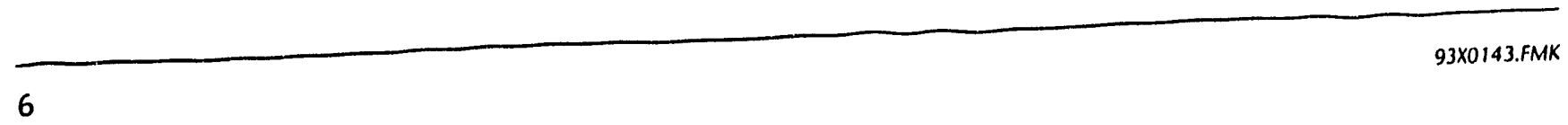




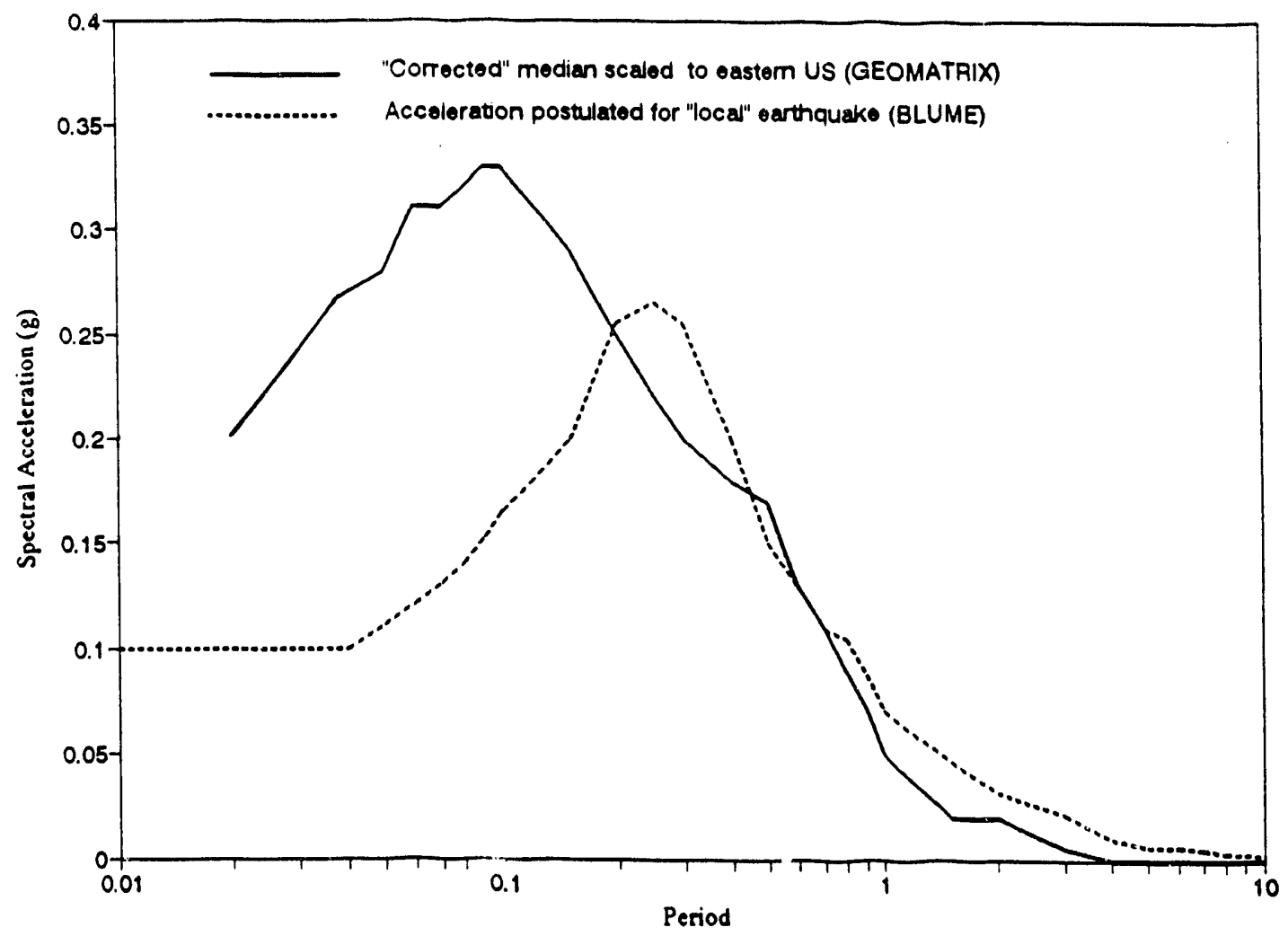

Figure 3. Horizontal statistical spectra for local event $\left(M_{w}=5.0\right)$ 


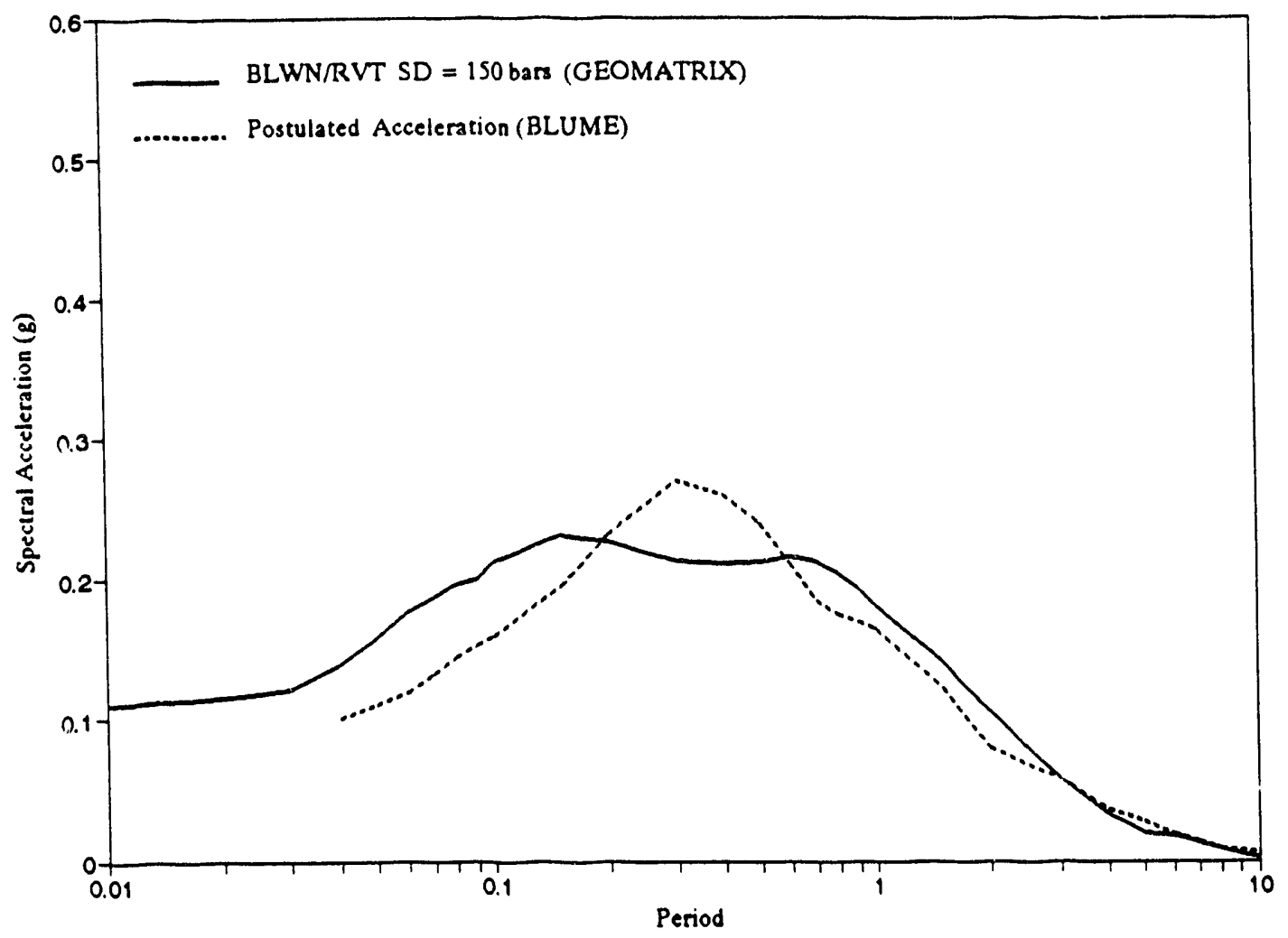

Figure 4. Horizontal statistical spectra for Charleston-type earthquake 

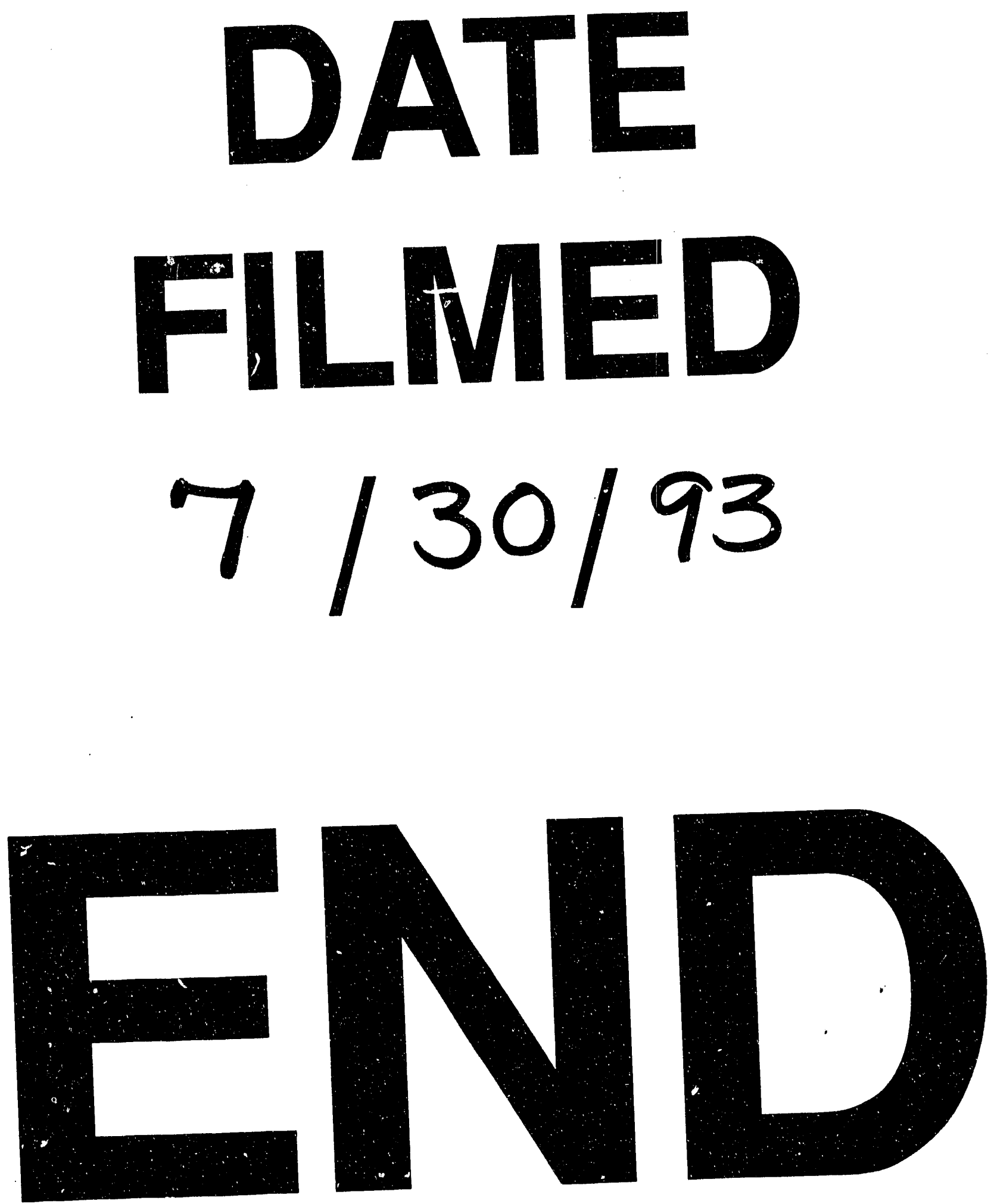
